ISSN 1027-5495. Functional Materials, 23, No.2 (2016), p. 337-343

doi:http://dx.doi.org/10.15407/fm23.02.337

(C) 2016 - STC “Institute for Single Crystals"

\title{
A new textile sizing prepared by the hemp core cellulose ethers
}

\author{
Zhang Xin ${ }^{1}$, Ji Yingchao', Wang Ying ${ }^{1}$, Wang Qiuhong ${ }^{1}$, \\ Zhang Qingli', Yu Zhihua ${ }^{2}$
}

\author{
${ }^{1}$ School of Textile and Material Engineering, Dalian Polytechnic \\ University, Dalian, 116034, China \\ ${ }^{2}$ Dalian Hualong Filter Clothing Co., Ltd., Dalian, 116034, China
}

Recieved November 5, 2015

\begin{abstract}
As the key process of weaving, sizing is one of the processes which are of great costly and serious pollution in the whole cotton-textile production. Great efforts have been made to study new kinds of sizing to reduce costs and environment pollution. In this paper, hemp cellulose ethers of Methyl cellulose (MC) ether and Hydroxypropyl methyl (HPMC) cellulose ether further were used as a kind of textile sizing. The results indicated that the MC and HPMC blended by 1:1 of sizing efficiency was similar to thos e of PVA. After sizing with this new kind of size, the breaking strength and elongation at break could replace sizing property of PVA, even extending beyond PVA. Compared to COD in the desizing wastewater of $30240 \mathrm{mg} / \mathrm{L}$ of PVA, the COD of hemp cellulose ether sizing was very small of $13235.2 \mathrm{mg} / \mathrm{L}$. Therefore, it is concluded that the hemp core ether is a new and environment-friendly textile sizing, which has low cost and contributes a healthier ecosystem.
\end{abstract}

Keywords: textile sizing, hemp core, cellulose ethers, substitute PVA

Изучены новые виды проклейки тканей с целью снижения издержек и загрязнения окружающей среды. Эфир метилцеллюлозы (MC) и эфир гидроксипропил метилцеллюлозы (ГПМЦ) использовали в качестве текстильной проклейки. Результаты показали, что эффрективность проклейки смесью МС и ГПМЦ в соотношении 1:1 аналогична эффрективности проклейки с помощью ПВА. После применения нового вида проклейки прочность на разрыв и относительное удлинение при разрыве аналогичны ПВА или даже могут превзойти их. Химическое потребление кислорода (ХПК) сточной воды, после отмывки проклейки на основе ПВА, составляющей 30240 мг/л, ХПК сточной воды после проклейки на основе эфира целлюлозы конопли - 13235.2 мг/л. Сделан вывод, что әфир гидроксипропил метилцеллюлозы представляет собой новый экологически чистый вид тканевой проклейки, которая имеет низкую стоимость и является более экологически чистым.

Розробка, властивості та застосування в промисловості ефірів, отриманих 3 серцевини конопель. Zhang Xin, Ji Yingchao, Wang Ying, Wang Qiuhong, Zhang Qingli, Yu Zhihua

Вивчений новий вигляд проклеювання тканин з метою зниження витрат і забруднення навколишнього середовища. Эфір метилцелюлози (MC) і еdpip гідроксипропіл метилцелюлози (ГПМЦ) використовували як текстильне проклеювання. Результати показали, що ефективність проклеювання сумішшю МС і ГПМЦ в співвідношенні 1:1 була аналогічна ефективності проклеювання 3 допомогою ПВА. Після застосування нового вигляду проклеювання міцність на розрив і відносне подовження при розриві можуть замінити проклеюючі властивості ПВА або навіть перевершити їх. Хімічне споживанняе кисню (ХПК) стічної води, після проклеювання на основі ПВА, і що становить 30240 мг/л, ХПК стічної води при використанні проклеювання на основі ефіру целюлози конопель - $13235.2 \mathrm{Vmг/л.}$ Зроблений висновок, що ефрір гідроксипропіл метилцелюлози е новий екологічно чистий вигляд тканинного проклеювання, яке має низьку вартість і $є$ більш екологічно чистим. 


\section{Introduction}

Polyvinyl alcohol is one of the common water-soluble polymers. Its the molecular chain is carbon chain, every repeat unit contains a hydroxyl. Because of the small size of hydroxyl and the strong polarity, which is easy to form hydrogen bonds. Therefore, the PVA has good water-solubility, film-forming property, cohesive force, emulsification, oil resistance, solvent resistance and low toxicity [1]. The sizing film of PVA has high strength, good abrasion resistance, and good adhesiveness for cotton, viscose fiber, and so on [2]. The serious disadvantage of the PVA sizing is a series of environmental problems. As the reason that PVA is difficult to degradation, the desizing wastewater after sizing contains a large number of hard degradation of PVA. The hard degradation is one of the main causes of the high COD value of printing and dyeing enterprises' wastewater in textile. Nowadays, the environmental problems of destruction and pollution have drawn extensive attention of all over the world [3]. Since the 1970s, the first proposed limit warp sizing using PVA in the United States and other European Union countries have successively started to ban the using of PVA. Subsequently, China start with less or no PVA in textile industry instead of using environmentally friendly sizing with clean production, saving-energy and emission reduction [4-5].

China is an agricultural country which is very rich in the resources of straw about $30 \%$ of the world total straw at the top of the world. According to a survey, the straw utilization rate is about $33 \%$ and mostly without processing and after dealing with the technology accounts for only about $2.6 \%$ in China.

If the large number of agricultural solid waste (especially the crops straw) fully developed and utilized. It can not only reduce the waste of resource and improve the environmental pollution, but also can produce huge economic benefits and good social benefits [6].

Cellulose, alkali and etherification agent react and generate a material which called cellulose ether under certain condition. It is one of the cellulose derivatives that cellulose macromolecule hydroxyl replaced by ether groups partly or overall [7]. Therefore, this paper based on waste hemp core as raw material to prepare two kinds of cellulose ether (methyl cellulose ether, hydroxypropyl methyl cellulose ether) and two kinds of cellulose ether as a new kind of textile size to replace PVA.

\section{Experimental}

\subsection{Materials.}

Chemicals used during the present study were sodium hydroxide, methyl chloride, epoxy propane, nitrogen, isopropyl alcohol, and acetic acid.

The hemp was planted in Yunnan province, China. Before the experiment, it was washed in the flowing water three times, dried and ground into powders. The degree of polymerization of hemp core cellulose is about 600 .

PVA was purchased in Changcun Petrochemicals Co. Ltd. Commodity name is BP-17 with viscosity of 21-26, Alcoholysis of 86-89 and $\mathrm{PH}$ of 5-7.

Alkali cellulose. Cellulose is a polymer combing crystalline part and amorphous part, which is linked by various forms of hydrogen bonding between cellulose macromolecules. The existence of large numbers of hydrogen bonds causes the low reactivity of cellulose. Then, it must be done by an activation treatment.

The reaction between alkali and cellulose generates new compounds - alkali cellulose. The physical chemistry will happen to dissolve cellulose and produce swelling partly ( the part of low molecular weight); The macromolecular glucose of cellulose change in the structure of position mutually to generate structural variant, which is accompanied with the increasing reactivity of cellulose. It is not to be ignored that the presence of water in the alkali's treatment, which has highly polarized characteristics that can permeate the cellulose to damage the remainder hydrogen bond belongs to atomic valence bond force [8].

It is the key to prepare the alkali cellulose that the ratio of every components in alkali cellulose (water, alkali, cellulose). The proportion of alkali to water affects the speed of etherification reaction and degree of substitution of cellulose ether in cellulose. However, the proportion of cellulose to water determines the degree of side effects. In other words, as a certain number of cellulose that the concentration of alkali determines the speed and degree of the main and side etherification reaction.

In the same temperature of etherification, the high concentration of alkali has a larger starting resistance at the beginning of etherification procedure, once the etherification began with a fast reaction rate. On the contrary, the low concentration of alkali has a low reaction rate. With the etherification reaction and side reaction proceed, the consumption of alkali and 
generation of water constantly which make the etherification reaction rate decreased even stopped. The suitable concentration of high viscosity cellulose ether is $30 \% \sim 50 \%$. In this paper, select the concentration of alkali was $35 \%$.

Squeezing alkali cellulose. The rate of etherification reaction must be controlled that pressing rate in the alkali cellulose to control the water content of the alkali cellulose in addition to the alkali concentration. If the water content increase, it affects the alkali concentration to make the reaction lowly. What's more, the etherifying agent will hydrolyze in the water environment. This side reaction can decrease the efficiency of etherification considerably. After many times tests this paper selected the squeezing alkali cellulose as 1.2:1:1.

Alkali cellulose aging. It is called the aging process that the aldehyde acetal group was fractured on the macromolecule of the alkali cellulose. With the increasing number of aldehyde fractured, the molecular weight and degree of polymerization decrease which make the lower viscosity in production of cellulose ether [9]. Therefore, Alkali cellulose aging has a important significance for controlling the viscosity of cellulose ether (that is the degree of polymerization). Avoid contacting with oxygen that lessens aging time in order to prepare high viscosity cellulose ether in this paper.

First, hemp core cellulose and $35 \% \mathrm{NaOH}$ solution were transferred to a kneader. The sample was stirred and steeped at room temperature for $2 \mathrm{~h}$. Subsequently, squeeze it to be molar ratio of $\mathrm{NaOH} /$ cellulose $/ \mathrm{H}_{2} \mathrm{O}$ as 1.2:1:1. The alkali cellulose avoid air oxidation in order to prepare high viscosity of cellulose ether in this article.

\subsection{Methyl cellulose ether (MC).}

Preparation of MC. The alkali cellulose was transferred to a reaction kettle with liquid methyl chloride under vacuum conditions. The reaction was being at 70 for $4 \sim 6 \mathrm{~h}$ and pressure of reaction was $3.0 \times 10^{5} \mathrm{~Pa}$.

At the end of the reaction, the material was neutralized by a $10 \%$ acetic acid solution, filtered on a sintered crucible, and then washed with ethyl alcohol. The methyl cellulose ether was dried in an oven at $80^{\circ} \mathrm{C}$ [10]. The molecular structure of methyl cellulose is showed in Fig. (1).

Influence on $M C$. Due to the alkali cellulose is not soluble in the methyl chloride, the etherification reaction of the synthesis of methyl cellulose is in the presence of multiphase system. Role in etherification reaction between each component in:

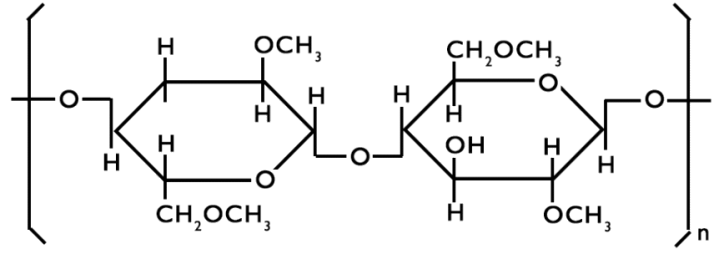

Fig. 1. The molecular structure of methyl cellulose.

The main reactions are listed in Eq. (1):

$\mathrm{R}(\mathrm{OH})_{3}+\mathrm{CH}_{2} \mathrm{Cl} \rightarrow \mathrm{R}(\mathrm{OH}) \cdot\left(\mathrm{OCH}_{3}\right)+\mathrm{HCl}$

$$
\mathrm{HCl}+\mathrm{NaOH} \rightarrow \mathrm{NaCl}+\mathrm{H}_{2} \mathrm{O}
$$

The side reactions are listed in Eq. (2-3):

$$
\begin{gathered}
\mathrm{H}_{2} \mathrm{O}+\mathrm{CH}_{3} \mathrm{Cl} \rightarrow \mathrm{CH}_{3} \mathrm{OH}+\mathrm{HCl} \\
\mathrm{NaOH}+\mathrm{HCl} \rightarrow \mathrm{H}_{2} \mathrm{O}+\mathrm{NaCl} \\
\mathrm{CH}_{3} \mathrm{OH}+\mathrm{CH}_{3} \mathrm{Cl} \rightarrow \mathrm{CH}_{3} \mathrm{OCH}_{3}+\mathrm{HCl} \\
\mathrm{R}(\mathrm{OH})_{3}+\mathrm{CH}_{3} \mathrm{Cl} \rightarrow \mathrm{R}(\mathrm{OH}) \cdot\left(\mathrm{OCH}_{3}\right)+\mathrm{HCl}
\end{gathered}
$$

Throughout the above reaction, in order to increase the quantity of reactant $\mathrm{CH}_{3} \mathrm{Cl}$, the maximize squeezing water content of alkali cellulose is needed to reduce the side effects and improve the efficiency of etherification. Second, it is better for etherification reaction keep at certain temperature from dynamic view .

\subsection{Hydroxypropyl methyl cellulose ether (HPMC).}

Preparation of HPMC. The squeezed alkali cellulose (1.2:1:1) was transferred to a reaction kettle, and then added the thirty parts of epoxy propane and seventy parts of methyl chloride under vacuum condition. The reaction was being at $50{ }^{\circ} \mathrm{C}$ for $3 \mathrm{~h}$ and pressure of $3.0 \times 10^{5} \mathrm{~Pa}$. Then, the reaction did again at $80{ }^{\circ} \mathrm{C}$ for $3 \mathrm{~h}$ and pressure of $3.0 \times 10^{5} \mathrm{~Pa}$ [11].

The end of the reaction, the unreacted etherification agent was recycled and material was neutralized by a $10 \%$ acetic acid solution, filtered on a sintered crucible, and then washed with acetone 2 or 3 times. The Hydroxypropyl 


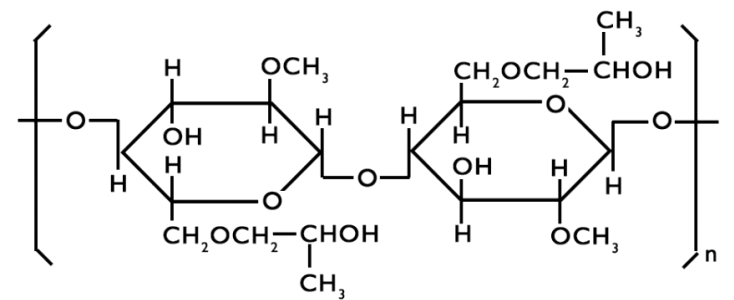

Fig. 2. The molecular structure of hydroxypropyl methyl cellulose.

methyl cellulose ether was dried in an oven at $80^{\circ} \mathrm{C}$ [12]. The molecular structure of Hydroxypropyl methyl cellulose is showed in Fig. 2.

Influence on HPMC. In the etherification stages of HPMC production, there are methylation and hydroxypropyl reactions. This reaction conditions are different and both positive and negative reaction rates also have bigger difference. The difference and coordination in the reaction conditions is what makes the complexity and unpredictability during the production process of HPMC.

Reaction of hydroxypropyl for around $30^{\circ} \mathrm{C}$ can be performed and the reaction rate greatly accelerated in $50^{\circ} \mathrm{C}$; The reaction of Methoxy is slower under $60^{\circ} \mathrm{C}$, even weakly below $50^{\circ} \mathrm{C}$. According to the different reaction temperature, controlling a certain temperature to make one for the main reaction was necessary. This article chooses in $50 \sim 60^{\circ} \mathrm{C}$ for a period of time which is the reaction of hydroxypropyl mainly. Then control the heating rate in a certain time period, which rose to give priority to with methylation reaction as the second etherification reaction stage and reaction temperature was $75^{\circ} \mathrm{C}$.It has reached the balance hydroxypropyl and methoxy and got the reasonable structure of the product. The multi-stage control technology is also conducive to reduce side effects and post-processing [13].

FTIR analysis. A FTIR spectrum of One-B (PerkinElmer co., Ltd, USA) was used to identify possible hemp core cellulose ether chemical alterations. The resolution is less than $2 \mathrm{~cm}^{-1}$.

In order to investigate the chemical structure of the cellulose ether, the FTIR measurement was carried out. Fig. 3 showed the FTIR spectra of MC and HPMC prepared by the hemp core cellulose. Curve a was the spectrum of MC and curve $b$ was the spectrum of HPMC. In the curve a, the characteristic peaks of $3435 \mathrm{~cm}^{-1}$ was the $-\mathrm{OH}$ stretching vibration, $2918 \mathrm{~cm}^{-1}$ was the $-\mathrm{CH}_{2}$ stretching vibration, $2837 \mathrm{~cm}^{-1}$ was the $-\mathrm{CH}_{3}$ stretching vibration and the $1394 \mathrm{~cm}$ 1 was the $-\mathrm{CH}_{3}$ deforming vibration. These

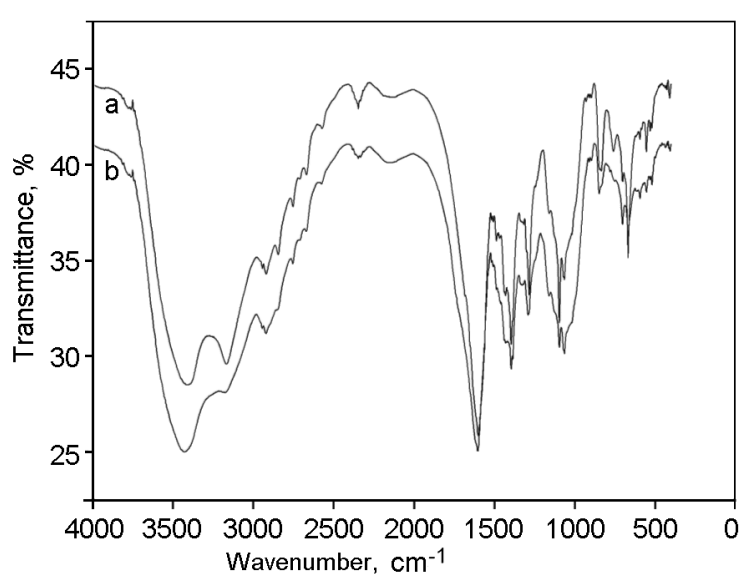

Fig. 3. FTIR spectra of MC and HPMC

methyl characteristic peaks clearly indicated that the $-\mathrm{OH}$ had been partly instituted by the methyl. The absorption band at $1067-1136 \mathrm{~cm}^{-1}$ belonged to the -C-O- and -C-C-C-peaks in the primary and second hydroxyl. It is to noted that the characteristic peaks in curve b were similar to those in the curve a. After the $-\mathrm{OH}$ was substitute by the $-\mathrm{OCH}_{2} \mathrm{CHOHCH}_{3}$, there was only a little band shift in the spectrum according to different degrees of substitution.

\section{Serum and sizing performance test}

Viscosity. The viscosity of MC and HPMC was measured with a DV-79 Viscometer. Before the measurement all the pastes were diluted to the concentration of $2 \mathrm{wt} \%$.

Effect of paste viscosity. The viscosity is an important parameter to textile sizing. The paste viscosity of MC and HPMC blends were shown in Table 1. It was clearly to see that the viscosity of $\mathrm{MC}$ was small. It was $1.85 \mathrm{mPa}$ : at room temperature. However, the viscosity of HPMC was big. It was $261 \mathrm{mPa}$ s at room temperature. In order to achieve sizing viscosity, the MC and HPMC ethers were blended according to different proportion, finally, obtain the expected viscosity.

$C O D$ determination. The method of $C O D$ test. The mainly pollution of desizing-wastewater depends on the selected size, therefore it is important to environmental performance testing analysis of size. Chemical oxygen demand (COD) is an important indicator to measure environmental protection of size. It shows that the higher COD of size impact on the environment heavily, on the contrary, the lower COD is friendly to environment. COD test as that GB/T 11914-1989 (the determination of chemi- 
Table 1. Result of Viscosity of MC and HPMC

\begin{tabular}{|c|c|c|c|}
\hline \multirow{2}{*}{} & \multicolumn{3}{|c|}{ Viscosity/mPa $\mathrm{s}\left(2 \mathrm{wt} \%, 25^{\circ} \mathrm{C}\right)$} \\
\cline { 2 - 4 } & $30 \mathrm{~min}$ & $90 \mathrm{~min}$ & $150 \mathrm{~min}$ \\
\hline HPMC & 261 & 255 & 1.83 \\
\hline MC & 1.85 & 1.90 & 92.6 \\
\hline $10 \mathrm{wt} \% \mathrm{MC}+90 \mathrm{wt} \% \mathrm{HPMC}$ & 93.1 & 89.7 & 41.1 \\
\hline $20 \mathrm{wt} \% \mathrm{MC}+80 \mathrm{wt} \% \mathrm{HPMC}$ & 38.7 & 37.5 & 14.9 \\
\hline $40 \mathrm{wt} \% \mathrm{MC}+60 \mathrm{wt} \% \mathrm{HPMC}$ & 12.7 & 16.0 & 7.22 \\
\hline $50 \mathrm{wt} \% \mathrm{MC}+50 \mathrm{wt} \% \mathrm{HPMC}$ & 7.58 & 7.17 & 6.16 \\
\hline $60 \mathrm{wt} \% \mathrm{MC}+40 \% \mathrm{HPMC}$ & 6.21 & 5.86 & \multirow{2}{*}{} \\
\hline
\end{tabular}

cal oxygen demand (COD) of water quality-dichromate method) [14].

Calibration of ammonium ferrous sulfate: First, the $5.0 \mathrm{~mL}$ standard solution of potassium dichromate move in the conical flask and thin with water to $40 \mathrm{~mL}$. Then, add $5 \mathrm{~mL}$ concentrated sulfuric acid slowly and shake well. Add 2 3 drops ferrous indicator after cooling and titrate solution with ammonium ferrous sulfate solution from yellow to red pass through blue-green. Second, take $5.0 \mathrm{~mL}$ water sample mixed evenly in the ground-glass stoppered flask, then, add $5.0 \mathrm{~mL} \mathrm{~K}_{2} \mathrm{Cr}_{2} \mathrm{O}_{7}$ standard solution and a few small glass beads (in case explosion-proof boiling). Subsequently, add $5.0 \mathrm{~mL} \mathrm{Ag} \mathrm{SO}_{4}-\mathrm{H}_{2} \mathrm{SO}_{4}$ solution in heating reflux 2h. Third, Add 3 drops ferrous indicator after cooling and titrate solution with ammonium ferrous sulfate solution from yellow to red pass through blue-green. The volume of consumption record as $\mathrm{V}_{0}$. Finally, the volume of consumption that making the above process with $5.0 \mathrm{~mL}$ distilled water. The COD value is calculated on the basis of the formula:

$$
\operatorname{COD}(\mathrm{mg} / \mathrm{L})=\frac{\mathrm{C}\left(V_{1}-V_{2}\right)}{V_{0}} \times 8000
$$

where,

$C$ - ammonium ferrous sulfate standard solution concentration;

$V_{1}$ - for the blank test by ammonium ferrous sulfate volumetric solution volume;

$V_{2}$ - by sample consumes the ammonium ferrous sulfate volumetric solution volume;

$V_{0}$ - the volume of the sample.

The result of $C O D$ test. Boiled pulp slurry of $1 \%$ concentration under $95^{\circ} \mathrm{C}$ after $1 \mathrm{~h}$ and

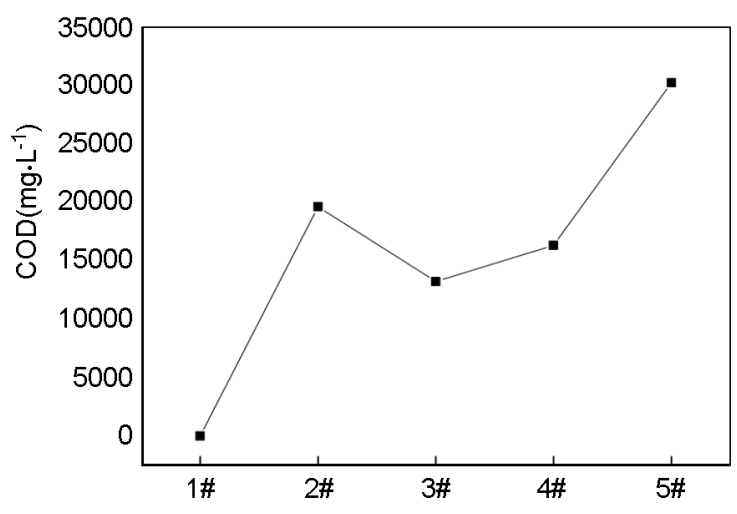

Fig. 4. The COD value of different sizes HPMC

measure COD in 1 hour later. It is shown in Table 1 and Fig. 4.

The desizing wastewater of PVA (0\#) was very big as $30240 \mathrm{mg} / \mathrm{L}$, however the COD of the mixed hemp cellulose ether sizing was very small of $13235.2 \mathrm{mg} / \mathrm{L}$. Thus it can be said that the new sizing is a green sizing. It is better than the traditional PVA sizing in PVA sizing environment area.

Sizing. Sizing procedure. Sizing tests were conducted on a GA310 Sizing Machine with a yarn speed of $5 \mathrm{~m} / \mathrm{min}$. Cotton yarns were impregnated with sizing paste at $95^{\circ} \mathrm{C} \pm 3^{\circ} \mathrm{C}$ and squeezed two times with a pair of weighted rollers, dried with four drying cans at $110^{\circ} \mathrm{C}$

Table 2. Sizing formula and COD value

\begin{tabular}{|l|c|}
\hline \multicolumn{1}{|c|}{ NO. } & $\begin{array}{c}\text { COD value/ } \\
\mathrm{mg} / \mathrm{L}\end{array}$ \\
\hline 1\# Grey yarn & 0 \\
\hline 2\# 40wt\% MC +60wt\% HPMC & 19627.2 \\
\hline 3\# 50wt\% MC +50wt\% HPMC & 13235.2 \\
\hline 4\# 60wt\% MC + 40wt\% HPMC & 16332.8 \\
\hline 5\# PVA & 30240 \\
\hline
\end{tabular}


Table 3. Result of sizing property

\begin{tabular}{|l|c|c|c|c|}
\hline \multicolumn{1}{|c|}{ NO. } & $\begin{array}{c}\text { Breaking } \\
\text { strength /cN }\end{array}$ & $\begin{array}{c}\text { Enhance- } \\
\text { ment rate /\% }\end{array}$ & $\begin{array}{c}\text { Elongation } \\
\text { at break /\% }\end{array}$ & $\begin{array}{c}\text { Reducing } \\
\text { elongation } \\
\text { rate/\% }\end{array}$ \\
\hline 1\# Grey yarn & 344 & 0 & 4.39 & 0 \\
\hline 2\# 40wt\% MC +60wt\% HPMC & 417 & 21.22 & 5.94 & -35.31 \\
\hline 3\# 50wt\% MC +50wt\% HPMC & 426 & 23.84 & 5.89 & -34.16 \\
\hline 4\# 60wt\% MC + 40wt\% HPMC & 412 & 19.77 & 5.67 & -29.16 \\
\hline 5\# PVA & 416 & 20.93 & 5.31 & -20.96 \\
\hline
\end{tabular}

and wound onto a small beam. After sizing, a $40 \mathrm{~s} \times 40 \mathrm{~s}, 110 \times 76$ plane cotton cloth was weaved.

Sizing evaluation. Sizing enhancement rate and reducing elongation rate, had great influence on the weaving production efficiency and product quality. Sizing strength and breaking elongation of sizing performance test is relatively convenient widely adopted by to cotton mills [15]. Through the test of the sizing change of breaking strength, breaking elongation that can provide practical reference of sizing technology to improve sizing quality [16].

Sizing enhancement rate is the percentage of difference between the single yarn of fracture strength after sizing and the original accounted for the original yarn breaking strength, liked as the following equation:

$$
\mathrm{Z}=\frac{P_{1}-P_{2}}{P_{2}} \times 100 \%
$$

where

$\mathrm{Z}$ - increase rate, \%;

$P_{1}$ - sized yarn breaking strength, $\mathrm{cN}$;

$P_{2}$ - the original yarn breaking strength, $\mathrm{cN}$.

The elasticity and elongation properties of original yarn will be loss after warp sizing and should try to reduce the loss of elasticity and elongation in warp sizing process to keep its original elasticity and elongation [14]. It often called reducing elongation rate that the percentage of difference between the single yarn of elongation at break after sizing and the original accounted for the original yarn of elongation at break, listed as the following equation:

$$
\mathrm{D}=\frac{\varepsilon_{0}-\varepsilon_{1}}{\varepsilon_{0}} \times 100 \%
$$

where

$\mathrm{D}$ - minus stretch rate, \%;

$\varepsilon_{0}$ - the original yarn elongation at break, \%;

$\varepsilon_{1}$ - sizing elongation at break, $\%$.
This test on YG061 / PC electronic single yarn strength tester and the sample length is cutting $700 \mathrm{~mm}$ with clamp distance of $250 \mathrm{~mm}$. The tensile speed is $250 \mathrm{~mm} / \mathrm{min}$ and calculates the average of it in 20 times. The result of enhancement and reducing elongation rate after sizing with the cellulose ether mixed and the original yarn in Tab. 3. Through the above data, it is clear that the breaking strength and elongation at break could replace sizing property of PVA, even extending beyond PVA.

\section{Conclusions}

In this paper, MC and HPMC cellulose ethers were prepared by the hemp core and study the influencing factors of preparation. That 50wt\% MC +50wt\% HPMC used as a new textile sizing to substitute the traditional sizing PVA. The results showed that the indicators of sizing were similar to PVA. The COD in desizing wastewater of hemp sizing was very small compared to PVA. Therefore, the hemp core ether sizing is a new and environmentfriendly textile sizing.

\section{Acknowledgements}

This work was financially supported by the Dalian Hualong Filter Clothing Co., Ltd.

\section{References}

1. C. L. Song, Shanghai Textile, 4,. 1, 2008

2. Y. H. Sun, S. M. Zhou, , J. Tianjin Inst. .Text. Scie.Techn., .16, 71., 1997

3. X. D. He, J. T. Sun, L. M. Guo, Cotton Text. Techn., .37, 393, 2003

4. H. J. Cui, Shanghai Text. Scie.Techn., 37, 46, 2009.

5. M. Wang, X. D. Yu. , Shanghai, Text. Scie. Techn., 37, 49, 2009

6. X. P. LI, J, Luoy, Inst, Scie,Techn, (Natural Science Edition),.30, 8, 2010

7. Q. J. Zhang, Polyvinyl Chloride, 5, 22, 2007.

8. Y. K. Yin, Y. F. Chen, C. Y. Ha, J. Cellul Scie. Techn.,13, 37, 2005. 
9. Y. Yang, Jiangsu Chem.Industry, 22, 30, 1994

10. Raj K. Singh (2013). J. Therm. Anal. Calorim, 114, 809, 2013.

11. H. P. Xie, Cellulosic Fibre, 31, 8, 2001

12. B. Y. Shi, S. X. Wang. Hebei Chem Industry, 2, 6, 1991.

13. CSBTS(State Bureau of Technical Supervision) GB/T 11914-1989 .The determination of chemical oxygen demand (COD) of water quality-dichromate method[s]. Beijing: Standards Press of China, 1989
14. X. R. Fan, R. P. Rong, H. J. Ji., Textile warp size detection technology, BeiJing: China Textile \& Apparel Press, pp.224-225,2007

15. Y. M. Zhao, Y. M. Li, G. Gao, H. M. Liu, J. .South China Univ. Techn, 35, 83, 2007

16. W. D. Gao, X. R. Fan, H. B. Wang, et.al. Cotton Text. Techn. 26, 581, 1998 